\title{
Lip and Oral Cavity Cancer pTis TNM Finding v8
}

National Cancer Institute

\section{Source}

National Cancer Institute. Lip and Oral Cavity Cancer pT is TNM Finding v8. NCI

Thesaurus. Code C132694.

Lip and oral cavity cancer with a finding of carcinoma in situ. (from AJCC 8th Ed.) 